\title{
O223. Population pharmacokinetics of lopinavir and ritonavir in combination with rifampicin- based antitubercular treatment in HIV-infected children
}

\author{
C Zhang $^{1 *}$, P Denti ${ }^{1}$, USH Simonsson ${ }^{2}$, G Maartens $^{1}$, MO Karlsson ${ }^{2}$, H Mcllleron $^{1}$ \\ From Tenth International Congress on Drug Therapy in HIV Infection \\ Glasgow, UK. 7-11 November 2010
}

\section{Objectives}

Children with HIV associated tuberculosis often require co-formulated lopinavir/ritonavir (LPV/RTV)-based antiretroviral treatment with rifampicin-based antitubercular treatment (ATT). Rifampicin (RIF), a potent inducer of drug-metabolizing systems, profoundly reduces the bioavailability of LPV. The aims of this study were to develop an integrated population pharmacokinetic (PK) model describing LPV and RTV PK in children with and without concomitant ATT using two different dosing approaches and to estimate doses of LPV/RTV achieving target exposures during ATT in young children.

\section{Methods}

A population PK analysis was conducted in NONMEM. During ATT 15 children were given LPV with extra RTV (LPV/RTV ratio 1:1) and 20 children were given twice the usual dose of LPV/RTV (ratio 4:1) 12 hourly; 39 children without tuberculosis and 11 children undergoing repeated sampling after ATT were treated with standard 12 hourly doses of LPV/RTV (median LPV dose $11.6 \mathrm{mg} / \mathrm{kg}$ ). Goodness-of-fit plots and visual predictive checks were used to evaluate the models.

\section{Results}

In a one-compartment model with first-order absorption to describe LPV PK, and a one-compartment model with transit absorption for RTV, the dynamic influence of RTV concentration on the clearance of LPV was

${ }^{1}$ University of Cape Town, Cape Town, South Africa

Full list of author information is available at the end of the article modelled as direct inhibition with an Emax model. Allometric scaling for weight was used for clearance and volume of both LPV and RTV. During ATT, the relative oral bioavailability of LPV was reduced by $79 \%$ in children receiving twice the usual dose of LPV/RTV. The clearance of RTV was $18 \mathrm{~L} / \mathrm{h}$ with, and $13 \mathrm{~L} / \mathrm{h}$ without, ATT. The baseline clearance of LPV, when RTV was undetected, estimated $4.34 \mathrm{~L} / \mathrm{h}$. With increasing concentrations of RTV, clearance of LPV decreased in a sigmoid relationship (EC50 $0.051 \mathrm{mg} / \mathrm{L}$ ). Volume of distribution for LPV and RTV were 11.7 and $102 \mathrm{~L}$, respectively. Simulations predicted that children weighing 4-6, 6-8, 8-12 and 12-18 $\mathrm{kg}$ need respective doses of 65, 50, 37 and $30 \mathrm{mg} / \mathrm{kg} \mathrm{LPV/RTV} \mathrm{(4:1)} 8$ hourly in order to maintain LPV concentrations $>1 \mathrm{mg} / \mathrm{L}$ in at least $95 \%$ of children.

\section{Conclusions}

The model describes the drug-drug interaction between LPV, RTV and RIF. Using 8 hourly doses, approximately 2.5 to 5.5 times the standard doses are required to maintain therapeutic LPV concentrations in young children during ATT.

\section{Author details \\ 'University of Cape Town, Cape Town, South Africa. ${ }^{2}$ University of Uppsala, Uppsala, Sweden.}

Published: 8 November 2010

\section{References}

1. La Porte CJL, Colberes EPH, Bertz R, et al: Pharmacokinetics of adjusteddose lopinavir-ritonavir combined with rifampicin in healthy volunteers. Antimicrob Agents Chemother 2004, 48:1553-1560. 
2. Natella R, John van den A, Aline B, et al: Population pharmacokinetics of lopinavir predict suboptimal therapeutic concentrations in treatmentexperienced human immunodeficiency virus-infected children. Antimicrob Agents Chemother 2009, 53:2532-2538.

doi:10.1186/1758-2652-13-S4-024

Cite this article as: Zhang et al:: 0223 . Population pharmacokinetics of lopinavir and ritonavir in combination with rifampicin-based antitubercular treatment in HIV-infected children. Journal of the International AIDS Society 2010 13(Suppl 4):O24.

Submit your next manuscript to BioMed Central and take full advantage of:

- Convenient online submission

- Thorough peer review

- No space constraints or color figure charges

- Immediate publication on acceptance

- Inclusion in PubMed, CAS, Scopus and Google Scholar

- Research which is freely available for redistribution

Submit your manuscript at www.biomedcentral.com/submit
C Biomed Central 